\title{
The scope of financial institutions: in-sourcing, outsourcing, and off-shoring.
}

\author{
Gordon L Clark and Ashby H B Monkt, School of Geography and the Environment, \\ University of Oxford, Hinshelwood Road, Oxford OX1 3QY, UK and Faculty of Business and Economics, \\ Monash University, Caulfield VIC 3142, Australia, and +Collaboratory for Research on Global Projects, \\ Faculty of Civil and Environmental Engineering, Stanford University, Palo Alto CA 94305-4121, USA.
}

Contact. gordon.clark@ouce.ox.ac.uk; amonk@stanford.edu

\begin{abstract}
Based on the seminal paper by Ronald Coase and subsequent work by Oliver Williamson, Oliver Hart and others, explanations for the existence of firms typically hinge upon the advantages of internal coordination over the purchase of market services. In recent years, the standard theory of the integrated firm has given way to a concern about the relative advantages of in-sourcing over outsourcing, recognising that the scope of the firm is a strategic matter. The issue of in-sourcing versus outsourcing has been accompanied by a concern about the geographical scope of the firm: whether the outsourcing of tasks and functions is close-at-hand or offshore. In this paper, we begin with reference to Ronald Coase and the literature that has followed in his wake and suggest, in the first instance, a way of conceptualising the tasks and functions of firms which rely upon firm-specific strategic assets including human capital, governance and decision-making procedures, and the information systems that underpin decision-making. The objects of our analysis are financial institutions like pension funds, sovereign wealth funds, and investment management institutions. To the extent that the cost of services is important, these types of financial institutions have sought to discount these costs by outsourcing, even offshoring. At issue is the viable geographical reach of this type of institution. In large part, our analysis is conceptual and theoretical rather than directly empirical. Nonetheless, it is based on a set of case studies and fieldwork and the implications to be drawn thereof.
\end{abstract}

Keywords. Financial institutions, coordination, in-sourcing, outsourcing, offshoring

JEL codes. D02, D21, G23, G32

Acknowledgements. The authors are pleased to acknowledge the support of Stanford University, and members of the research consortium coordinated by the Collaboratory for Research on Global Projects in the Faculty of Civil and Environmental Engineering. Support for research on the governance and management of investment institutions has been provided by the Leverhulme Trust, the Rotman International Centre for Pension Management, and TowersWatson. The authors wish to thank Keith Ambachtsheer and Roger Urwin for their continuing interest in our research programme. Since the paper draws, in part, upon previous research on the role and significance of fixed assets and sunk costs in corporate strategy, the authors also wish to record their indebtedness to past collaboration with Neil Wrigley. None of the above should be held responsible for the views and opinions expressed herein. 


\section{Introduction}

Institutional investors dominate global financial markets (Morrison and Wilhelm 2007). At one level, they are conduits for 'consumers' seeking access to financial services including pensions, insurance, and much else besides. At another level, they are like any other firm in that they must organise the production process so as to realise a priori objectives. This may involve deploying their own assets so as to produce financial products just as it may involve decisions as to what services to purchase from the market. The issue of in-sourcing versus outsourcing dominates much of the literature about the nature and scope of firms (Hart and Holmstrom 2010). It resonates with related research in economic geography and management studies as to the functional and geographical scope of firms in specific industries and political jurisdictions (Dicken 2000; Lowe and Wrigley 2010). This paper seeks to explain the logic and structure of financial institutions with respect to the scope of their tasks and functions as well as their geographic reach.

Banks and the banking systems of developed economies have been the subjects of considerable research as to their commonalities and differences (Thakor 1996). See also the research on the relative status of banks versus markets, comparing continental European countries with AngloAmerican countries (Dore 2000 and Hall and Soskice 2001). The global financial crisis and the euro crisis have served to emphasise the significance of these institutions, as if they are singularly and together at the epicentre of financial decision-making. As important, however, are pension funds, mutual funds, sovereign wealth funds, foundations, endowments and family offices. The latest available data suggest that they hold in aggregate about $\$ 30$ trillion, representing the savings and investments of hundreds of millions of people around the world (Pensions \& Investments, $26^{\text {th }}$ December 2011). Notwithstanding their vast financial assets, these institutions are often invisible in commentaries about the structure and performance of financial markets (Allen and Gale 1994).

How these institutions are organised, how they coordinate their activities, and how they intersect with the market for financial services are crucial topics of research. In tackling these issues, we draw upon the relevant literature on the size and scope of the modern firm beginning with Coase (1937) who sought to explain why firms exist, what determines their size, and how the costs of market intermediation may be managed by the firm. Importantly, he provided a model of the firm in time and space, arguing that the geographical reach of the firm is a function of the relative efficiency of communication technologies. His research has been extended by those who focus upon the nature of contract inside and outside of the firm, distinguishing between discrete contracts and relational contracts and the degree to which contracts are fully-formed or are, in important ways, 'incomplete' (see Hart and Moore 1999).

In this paper, we analyse the scope of financial institutions in terms of the choices facing managers given the distinctive industry and national environments in which they are located. As such, it is assumed that choice is mediated by the environment and the strategic assets of firms recognising that both can provide opportunities as well as constraints on decision-making. Conceptualising choice in this manner follows recent arguments in favour of taking seriously the context that frames corporate structure and behaviour (see Dicken and Malmberg 2001) and, more generally, analytical frameworks that emphasise the relational elements of economy, geography, and society (Bathelt and Glückler 2011). Inevitably, this suggests that decision-making is boundly-rational and, as such, is structure-sensitive if not structure-determined (Clark 1994). It is noted, moreover, that the size of an institution (assets-under-management) (AuM) is fundamentally important in determining its potential reach and its relative reliance upon the market for financial services.

At issue is the degree to which financial institutions like pension funds and sovereign wealth funds internalise the tasks and functions necessary to be effective investors given their AuM and the 
industry and firm-specific assets that they require to underwrite competitive strategies in this domain. To understand the nature of the constraints on decision-making, we explain the significance of assets-under-management as well as what counts as firm-specific strategic assets. Unlike companies in manufacturing and retail sectors (Wrigley et al. 2005), investment institutions have little in the way of tangible or fixed assets, relying, instead, on human capital, governance procedures, and the information-processing infrastructure that supports human capital and decision-making. This discussion serves as the basis for analysing the choice whether to in-source or outsource to the market certain tasks and functions and whether to offshore the provision of tasks and functions either within or without the investment institution. In this respect, we analyse the geographical scope of investment institutions, drawing upon the related literature in economic geography on the role of complementarities in driving the spatial concentration of the industry (Clark 2002).

Emphasised are principles rather than the specifics of any particular company, institution, or jurisdiction. This strategy may be thought to violate the norms associated with contemporary treatments of the firm in economic geography (Taylor and Asheim 2001). Nonetheless, inspiration for the paper comes from a series of case studies of the structure and management strategies of investment institutions and, in particular, their approach to the issues of in-sourcing and outsourcing as well as offshoring within and without the institution. While we recognise that the notional 'identity' and legal form of the firm is important in any comprehensive mapping of the nature of the firm in the global economy, in this paper we are more concerned with how investment institutions are organised and function given the imperatives associated with the global financial industry (along the lines suggested, separately, by Dixon 2012 and Maskell 2001).

\section{Theory of the Firm}

For Coase (1937), the issues were obvious: why do firms exist? Why do entrepreneurs in-source tasks and functions which could be obtained in the market? Before providing an analytical framework and answers to these questions, Coase opens with a statement on methodology emphasising the need for a "tractable" and "realistic" perspective centred upon the role of the "entrepreneur-coordinator". We share his interest in a "tractable" and "realistic" perspective, emphasising what is distinctive about financial institutions. Coase follows classical theorists like Adam Smith, buttressed by the analytical instruments provided by Alfred Marshall. His analysis was revealing and resonates with the experience of many investment institutions, especially as regards the importance of senior managers as coordinators where the 'principal' is either so abstract or so remote as to be irrelevant. In many jurisdictions, these types of institutions act on behalf of 'silent' beneficiaries subject to legal requirements of behaviour including fiduciary duty (Woods 2011).

Coase contended "the main reason why it is profitable to establish firms would seem to be that there is the cost of using the price mechanism" (ftn. p.390). This claim is explained by reference to a number of issues. First, and most obvious, there are costs associated with price discovery determining the best market price for a set of services distinguished by their quality and quantity is challenging and, if intermediaries supply information, expensive. His argument resonates with more recent treatments of search costs and market signalling as exemplified by Spence (1977) and Grossman et al. (1977). See also Grossman and Stiglitz (1980) who argue that information asymmetries are pervasive aspects of market economies. Coase suggested that the costs of negotiating and agreeing separate contracts for services are significant, especially if there are many contracts covering diverse and unrelated activities. The virtues of in-sourcing are twofold: first, the firm need offer only one contract or a limited set of contracts across a variety of employees (tasks and functions), and, second, contracts need not be as complete as they would have to be for market services, providing the entrepreneur flexibility to vary their terms and performance criteria over time. 
Coase also noted, in his time at least, taxes on transactions do not have to be paid on internal services. Therefore, a firm benefits from "the system of relationships which comes into existence when the direction of resources is dependent upon an entrepreneur" (p. 393). Coase provided an hypothetical example demonstrating that firms will tend to be larger when the costs of in-sourcing are lower than the costs of outsourcing and when the rate of increase in those costs with the number of transactions remains equal to or less than the costs of transacting in the market. He also suggested that firms will be larger than smaller when the costs of mistakes due to increasing institutional complexity remain less than the payoffs to be obtained from sourcing in the market. And finally, he contended that firms will be larger than smaller when the supply prices of internal factors of production are less than market prices. Importantly, he recognised that there may be decreasing returns to scale: at some point, it will pay the entrepreneur to outsource rather than insource services. There are three strategic variables with respect to managing the firm: the relative costs of services, the costs of mispricing services, and the complexity of the firm.

Coase also notes that "it seems improbable that the firm would emerge without the existence of uncertainty" (p.392). But he disputes Knight's (1921) contention that the existence of risk and uncertainty is the crucial factor driving the establishment of firms and, especially, their size. Nonetheless, it is apparent that the entrepreneur stands to gain from in-sourcing if markets are subject to significant information asymmetries that introduce risk and uncertainty when pricing inputs to production. There is a balance to be struck between the search costs involved in determining market prices and the costs associated with mispricing internal inputs to the production process. Equally, there is a premium on being able to vary production at low cost and with some frequency relative to the market for services in response to unanticipated changes in market conditions for final products. Throughout, he assumed that entrepreneurs have the authority and power to vary inputs to the production process in ways that can realise an optimal solution to the size and scope of the firm.

Importantly, he suggested that the spatial scope of the firm will be determined by the costs of coordination, whether internally or by market, and those costs increase with the spatial dispersion of transactions. Therefore, to the extent that the costs of coordination can be limited by the spatial concentration of production, firms will grow at centralised sites and dominate spatially-extensive consumer markets. He suggested that communication technologies such as the telephone and telegraph were crucial for reducing the cost of organising the firm over time and space (p.397). To make his point, he invokes von Thünen's theory of location to explain why and how there may be geographical patterns in the size and location of firms. While Coase provides a general theory of the firm, he does so recognising that industries and jurisdictions often have distinctive patterns of transactions and pricing practices such that vertical integration in one industry and one jurisdiction might not be the favoured solution for that same industry in another jurisdiction.

Grossman and Helpman (2005) have a similar approach to the problem of outsourcing. Like Coase, they suggest that offshoring is made possible by the efficiency of communication technologies and that these technologies, in recent years, have become remarkably quick and cost-effective. In Grossman and Rossi-Hansberg $(2008, p .1981)$ it is also suggested that some tasks and functions can be performed offshore better than others. Specifically, "the cost of offshoring a task may reflect how difficult it is to describe using rules-based logic, how important it is that the task be delivered personally, (and) how difficult it is to transmit or transport the output of the activity". This argument leads them to focus upon tasks and functions that are relatively straight forward, can be executed by low-skilled labour, and incur relatively low coordination costs. In effect, they assume that there is a relationship between the simplicity of tasks and functions and the costs of coordination over time and space - the decision to offshore is taken when tasks and functions can be conceived and 
executed according to well-defined and non-negotiable attributes and when communication technologies allow for the efficient and unambiguous transmission of instructions.

In many respects, Coase and Grossman and Helpman were concerned with the complexity of the production process. Coase's conception of complexity was, however, rather vague and lacking in substance. He hinted at organisational inefficiency and limits on market responsiveness by virtue of the confusion of overlapping tasks and functions. If considered in the light of recent research on cognition and decision-making (Kahneman and Tversky 1979), complexity could also be understood as an issue of entrepreneurs' limited cognitive resources: reflected in their limited capacity to conceptualise solutions and impose a hierarchical structure upon the component parts of coordination. Outsourcing and offshoring may accentuate this aspect of the coordination problem. In a related vein, complexity could also be understood as an issue of authority: the "entrepreneurcoordinator" may lack the power to enforce his or her (or their) desired priorities. By Jensen's (1993) assessment, complexity results in inertia reinforcing the 'rents' claimed by powerful and entrenched interests.

\section{Governance, Contract, and the Firm}

Coase's theory of the firm is familiar to contemporary theorists (Taylor and Asheim 2001). Even so, the importance attributed to the "entrepreneur-coordinator" appears less relevant given the significance of managed firms in modern economies (where owners are either absent or silent). It could be argued, of course, that the entrepreneur-coordinator stands for managers and the management process rather than the owner per se. But to do so would ignore one of the most important features of modern firms: they are hierarchies of authority characterised by different types of contracts, according to different levels of responsibility, tasks and functions (Williamson 1975). In this respect, the governance of the firm is of fundamental importance if 'owners' through their managers are to realise their objectives. On this issue, there is a large and growing literature on agency problems within firms (see Pratt and Zeckhauser 1985 and Schoenberger 1997).

For Coase, the employment contract is a device for coordinating the firm. For contemporary theorists, the employment contract is more than a coordination device: it is a means of conceptualising the modern firm (see Easterbrook and Fischel 1991 on the firm as a nexus of contracts) and a means of governing the firm, reconciling the interests of managers and workers by reference to the objectives of the firm (Jensen 2001). As such, contract theory claims centre stage when discussing the theory of the firm (see, for example, Hart 1995). It stands for a range of issues including the authority of managers, the responsibilities of workers, their respective rewards for commitment to the objectives of the firm, and expectations as regards their job tenure as against competing opportunities in the market. ${ }^{1}$ Given the nature of contract, it may be very difficult to fully-specify the terms of engagement, and their execution against prospective and unanticipated events (Hart and Moore 1999).

Following Hart and others, it is assumed that within the firm employment contracts are 'incomplete' and 'relational'. Given the transaction costs of complete contracts, it would seem that employees are first hired according to their 'fit' with prescribed tasks and functions and the appropriate

\footnotetext{
1 . In this respect, contracts embody incentives either formally through stated performance targets and explicit compensation regimes or informally through promises of future rewards for commitment to the objectives of the institution (Holmstrom and Milgrom 1994). This is a complex issue, made more so by the intrusion of government regulation into firm and industry compensation practices in relation to community standards and requirements as regards non-discrimination etc. As a consequence, firms have sought ways of introducing bonus and contingent incentive systems which supplement legally-enforceable contractual compensation commitments (see Roberts 2004).
} 
standards of compensation and then, as they gain experience and their tasks and functions evolve in response to the environment, the terms and conditions of employment are adapted to changing circumstances. As is well appreciated, these types of firms typically rely upon well-defined tasks and functions and formal mechanisms of evaluation; but internal labour markets often take precedence over external markets of services when seeking to quickly and effectively respond to changing circumstances. Continuity of contract facilitates on-the-job learning as well as the exploitation of firm-specific tacit knowledge (Gertler 2003). In this respect, employment contracts are not only incomplete, they are also relational in that they facilitate ongoing relationships between co-workers, managers and workers (Baker et al. 2002).

By contrast, it is assumed that contracts with external suppliers are, as-near-as-possible, complete and discrete. One reason managers contract with external providers is that they need not make any commitment, and may wish to avoid signalling any commitment, to suppliers who provide tasks and functions according to set terms and conditions. In this respect, contracts with external suppliers are assumed to be contingent upon performance and subject to termination at-will (with compensation). Compared to internal contracts, the market for services (tasks and functions) provides managers with the opportunity to realise their goals and objectives without making a commitment to the future. Indeed, they may vary the mix of internal and external suppliers so as to dampen the escalation of internal commitment and impose discipline on the expectations of their own employees. As such, there may be an efficiency gain in balancing (internal) relational and (external) discrete contracts as managers enforce their authority over the production process. Notice, outsourcing in this manner depends, surely, upon the simplicity of contractually-agreed tasks and functions (as suggested by Grossman and Helpman 2005).

The distinction between discrete and relational contracts is idealised. ${ }^{2}$ Even if governed by discrete contracts, suppliers may come to rely upon the firm for the flow of contracts thereby tying themselves to the firm. Equally, recognising the discrete nature of the contract, some suppliers may shirk their responsibilities as regards the quantity, quality, and the delivery of agreed tasks and functions. In this respect, the costs of ensuring compliance with a discrete contract may rise especially if the firm relies upon certain market suppliers for component parts of their production system. When suppliers are required to invest in capital stock and logistic systems to match the internal configuration of the firm, their reliance on discrete contracts may become a threat to their long-term survival. By this logic, both the firm and its suppliers may become enmeshed in knots of contracts that, in effect, carry implicit commitments akin to relational contracts (Monk 2008). Fealty to sunk costs on both sides of the relationship (firm and suppliers) may amplify reliance (Williamson 1975).

\section{[Insert Figure 1 About Here]}

In Figure 1, we summarise this discussion providing two sourcing options (internal and external) for the firm in two contractual regimes governing the relationship between the firm and the providers of tasks and functions. The standard way of representing in-sourcing and outsourcing by the nature of the contract are provided by instance $A$ and instance $D$ (top left box and bottom right box). As suggested above, however, outsourcing governed by discrete contracts may evolve such that

\footnotetext{
2/. Macneil (1980, pp. 10-11) characterised discrete contracts as 'primitive' compared to relational contracts that bind together interdependent economies with high levels of specialisation and exchange. More generally, discrete contracts are seen by some to be consistent with economic efficiency, providing the option for contractual partners to abrogate commitments as need be (subject to compensation). As such, discrete contracts are consistent with philosophical conceptions of liberal democracy where individual preference and choice trumps social commitment.
} 
instance $\mathrm{C}$ comes to play a significant role in the governance of firms' supply relationships. Equally, firms may well attempt to bifurcate the contractual regimes governing internal employment relationships, distinguishing between those employees with crucial skills and knowledge of the production process from those that have rather simple, replicable, and well-defined tasks and functions. To the extent that managers can maintain this type of distinction internal to the firm, instance $\mathrm{C}$ may well mimic the conditions obtaining in the market for related tasks and functions (instance D) rather than relational contracts. Job tenure may be limited, wages subject to market conditions, and firm-specific training non-existent.

Offshoring can be seen synonymous with outsourcing in that once the decision is made to seek suppliers of tasks and functions outside of the firm, it's a question of location near (instance B) or far away (instance D). See Figure 2. Here, the work of Gene Grossman looms large especially as regards the reliance of firms on advanced communication technologies, rule-based tasks and functions, and standardised production systems and technologies to manage their supply networks. This issue is normally cast in terms of suppliers located in less developed economies (instance D), transforming the pattern of trade from whole products into the trade of component parts of products assembled in the home location (instance A). The process of offshoring relies upon the co-existence of very different norms and conventions governing the workplace such that by virtue of distance and jurisdiction the firm can maintain its desired contractual arrangements (Currah and Wrigley 2004). This suggests managers may seek distant locations that are profoundly different by culture and standards of living. As indicated some years ago, however, these types of differences can be found in developed economies, distinguishing between advanced metropolitan regions and semirural and less-developed regions (instance B) (Clark 1981).

\section{[Insert Figure 2 About Here]}

Much of the literature tackles the issue of offshoring by reference to the relationship between the command centre of the firm and its distant sites of production. It is entirely possible that the production and delivery of firms' outputs may require in-sourcing at home and away in the sense that products may be comprised of components that are assembled and distributed around the world through the offices that represent the firm. In this respect, some companies in some industries may be multi-locational and require coordination between managers at the same level of the firm, as well as coordination between different tiers of the firm. This conception is developed in more detail in the following section. Here, it is assumed that outsourcing almost always carries with it a rather different contractual framework than obtained for in-sourcing. Whether in-sourcing at home and away involves a shared contractual framework distinctively different from external suppliers remains to be seen.

\section{The Institution and Its Industry}

Focusing upon the advantages of firms relative to market pricing, and the contractual norms that match stylised conceptions of in-sourcing, outsourcing and offshoring, we have provided the basic building blocks for firm structure and governance. As intimated above, however, the relevance and expression of these principles depend upon the "economic environment" or context in which the firm and its industry functions (see Baker et al. 2002, Sec.ll). In this section, we describe the distinctive attributes of financial institutions as they pertain to the issue of firm structure and governance. In doing so, the details of specific cases are eschewed in favour of a schematic or stylised representation of the essential features of these institutions.

To be specific, we distinguish between the process whereby assets-under-management are collected and lodged with our institution and the investment process itself. Elsewhere, Clark (2000) provides an historical and geographical account of the rise of Anglo-American pension fund capitalism and the 
associated financial services industry. Assuming our representative financial institution inherits or is provided by tender the stock of assets-under-management (ignoring gross flows for the moment), the 'size' of the institution is assumed given, but the scope of its activities is yet to be determined. This is an important point of clarification. More often than not, firm size and the scope of activities are confused or treated as synonymous. Importantly, our institution also relies upon global financial markets for the 'production' of investment returns. Just as managers seek information from the market for financial services, the investment performance of the institution is dependent upon the collection, analysis, and deployment of market-sensitive information. Information is the lifeblood of the organisation affecting its form and its functional performance.

We assume that our representative financial institution seeks to maximise the risk-adjusted rate of return either on its own behalf or on behalf of clients who neither express their preferences nor are able to self-organise to affect the institution's investment strategies and policies. We assume that the costs of producing the risk-adjusted rate of return are significant in that the net profit or the net return to beneficiaries is crucial in underwriting its reputation as a desirable investment manager. On the output side of the equation, it is assumed that the 'notional' product produced by the institution is the risk-adjusted rate of return; this income stream is produced by investing the available assets via (1) the manager's strategic asset allocation framework and (2) asset-specific (specialised) portfolio investment teams. ${ }^{3}$ Most importantly, our institution is a planning and decision-making entity that seeks to realise its objectives in the context of market risk and uncertainty (Clark 2008). Managers have responsibility for over-sight of the performance and decision-making of the institution's portfolio investment teams.

Here, there are two important distinctions that bear upon the hierarchical structure of the institution and the relationship between investment teams. We assume that strategic asset allocation is the responsibility of the institution's senior managers, informed, no doubt, by its target risk-adjusted rate of return and its available financial assets. There are, as well, specialised tools available for framing and implementing strategic asset allocation, including diagnostic tools aimed at determining institution-wide and portfolio-specific risk exposure. In this respect, portfolio investment teams are subsidiary to the institution's overarching goals and are, themselves, governed by a priori determined performance targets and risk budgets. At one level, portfolio investment teams are complementary activities in that the overarching strategic asset allocation 'formula' provides a means of coordinating portfolio investment teams (Clark 2002). At another level, however, portfolio investment teams are competitors for institutional resources and, especially, assets-under-management. The challenge is to provide incentives consistent with a priori performance objectives, while ensuring that their activities remain consistent with the overarching interests of the institution.

Whereas much of the social science research on the firm has as its object, implicitly or explicitly, firms that rely upon fixed or tangible assets, our institution relies upon three strategic assets that are quite unlike plant and equipment. Tasks 1 and 2 depend upon the institution's human capital and the governance of the institution - these are assets in the sense that human capital provides the intellectual resources to set strategic asset allocation and drive the performance of portfolio investment teams. Notice, human capital can be thought to be comprised of two elements: domain-

\footnotetext{
$3 \%$. In this paper, we are not able to consider the structure and performance of portfolio investment teams, and the challenges involved in reconciling the desirability of higher levels of team coherence and loyalty against the overarching goals of the institution (Che and Woo 2001). It is widely observed that some of the most successful portfolio investment teams are characterised by high levels of intimacy, personal commitment, and mutual benefit. They motivate one another, they monitor one another's commitment, and they reinforce their shared identity against the authority of institutions' managers (Teece 2000). It is not surprising that when 'star traders' are poached by other institutions they take with them their team members.
} 
specific training and education and talent. Here, it is assumed that common sense is no substitute for domain-specific skill (Wagner 2002). Talent refers to the ability of portfolio investment managers to exercise judgement as to the flux and flow of markets utilising so-called subjective as well as objective cues to inform decision-making in timely and effective ways (Hilton 2003). Governance can also be decomposed into two elements: coordination across the various tasks and functions essential for realising the risk-adjusted rate of return and authority for deciding upon the component parts of the institution. It is assumed that coordination is based upon procedures of management, whereas authority involves taking decisions as to the size and scope of the institution itself.

To summarise, Figure 3 sets-out the ways in which human capital and governance intersect and overlap to frame the institution. Each pair of elements provide an action 'space' in that highly talented individuals characterised by significant levels of specialised training and education are shown as instance A (portfolio managers and their teams) just as those that sustain the coordination of the institution, while assuming significant levels of responsibility for its overall performance and structure, are shown as instance B (senior managers). In a way, Figure 3 articulates the framework suggested by Coase, which underpins the modern theory of the firm distinguishing between those that coordinate the institution and those that realise its tasks and functions. In this case, because of the significance of market risk and uncertainty for the investment performance of the institution, both the governance of the institution and its employees are treated as strategic assets as well as factors of production.

Notice Figure 3 provides space for other related tasks and functions. For example, instance C indicates that some talent and authority are important for job performance (as in human resource management) and instance $D$ indicates that some training and education and a role in institutional coordination are important in job performance (as in IT provision). Being a four-sided box, it is assumed that there are other tasks and functions which are not located at the corners of the box.

\section{[Insert Figure 3 about Here]}

Underpinning this framework is a third strategic asset: the information infrastructure which informs managers responsible for governance and specialised portfolio investment teams responsible for performance. Financial market information is collected, presented, and distributed by market agents and intermediaries around the world. There are, of course, important market providers, such as Bloomberg, which dominate the distribution of financial information. However, our institution also seeks market information not so commodified in the hope of gaining advantage over its competitors, whether by identifying underlying trends or disjunctions or by testing-out competing expectations as to market performance. Equally important is the processing of information internal to the institution such that those responsible for investment strategy and those responsible for the coordination of the elements that make-up the institution's investment strategy know as much about risk exposure and market position as those that design and execute investments strategies. At one level, information infrastructure provides the tools to manage the whole institution. At another level, information infrastructure provides managers the information through which to exercise authority.

\section{Tasks and Functions}

Here, we analyse the configuration of our idealised financial institution in relation to its size and scope. We begin with its objective function and the means by which it seeks to realise that objective. As above, it is assumed that it seeks to maximise the risk-adjusted rate of return through (1) its strategic asset allocation framework and (2) the performance of its specialised portfolio investment teams. It does so with reference to the costs of producing its desired risk-adjusted rate of return 
and its strategic assets. It is also assumed our institution has its complement of managers - those responsible for setting the goals of the institution and deciding on its tasks and functions.

In-sourcing: assuming our institution has a modest sum of assets-under-management, the rate of return objective of the institution's managers may not match the strategic assets of the institutionbecause of its size, it may lack the requisite human capital, governance procedures, and infrastructure necessary to realise its ambitions in a cost-effective manner. Whereas conventional treatments of the firm assume that, in its embryonic form, managers do almost everything internal to the firm, in this case it would seem that almost everything is done outside the boundaries of the institution. At this level, there is a premium on the governance capacity of managers with respect to external providers; coordination and oversight of those providers are crucial if the institution is to realise its objectives. But, notice, they are likely to depend upon the reporting systems of external providers. In effect, our institution relies upon the human capital and economies of scale of external providers in the market for financial services.

As the institution grows in terms of its assets-under-management, managers are able to bring an increasing number of functions internal to the institution. Assuming that our institution retains an ambitious rate of return target, the functions brought internal to the institution are likely to be those that can be managed and executed in a cost-efficient manner. By this logic, in-sourcing depends upon (1) being able to allocate resources to a select number of functions which can meet or better the costs-of-provision of those same tasks and functions in the market for financial services. Insourcing also depends upon (2) being able to recruit the requisite human capital to realise the performance objectives of those functions in relation to the overarching strategic asset allocation framework. And finally, (3) in-sourcing depends upon a governance budget consistent with those functions complemented by an appropriate system of information infrastructure for facilitating institution-wide oversight and control. Investment in human capital and infrastructure is consistent with ensuring the long-term sustainability of in-sourcing policies.

At some level, assets-under-management will be sufficient to in-source the tasks and functions needed to realise the institution's objectives. We assume that managers choose to in-source so as to reap the benefits of being a firm as opposed to being simply a network of market providers. Coase suggested that these benefits include the standardisation of contracts, insulation from shortterm volatility in the market pricing of services, and the flexibility of incomplete or relational contracts given market risk and uncertainty. For our institution, and the financial services industry at large, these benefits are apparent and significant. Given their reliance upon human capital, institutions' managers use the relational nature of contract to insulate themselves from market competition for skilled and talented labour on the funds management side of the business. Equally important, relational contracts can provide senior managers with the 'breathing-space' to develop investment strategies that are distinctively different to their competitors. So, for example, some of the largest funds have made long-term commitments to portfolio managers who expertise in direct investments, infrastructure, and alternatives carry a market premium. In doing so, however, institutions may find it impossible to hold to a single, standardised contract. ${ }^{4}$

One response to the heterogeneity of tasks and functions has been to overlay each type of contract with a set of incentives and benefits that link compensation to the performance of the individual, the team, and the institution. Market-facing tasks and functions may claim a premium on short-

\footnotetext{
4. Differential compensation with these types of institutions is often more difficult when the institution is sponsored by a public body or agency. As a consequence, the advantages of in-sourcing may not be realised because of the lack of flexibility of senior managers with respect to standards of contract and remuneration. By this account, outsourcing may be more desirable, especially if there is little in the way of reporting requirements as regards the terms of external contract and engagement.
} 
term incentives linked to performance whereas governance tasks and functions may claim a premium on longer-term incentives linked to realising the institution's overarching target rate of return. Further, market-facing tasks and functions may be covered by relatively complete (discrete) employment contracts whereas executives may be offered open-ended contracts with incentive payments that stretch-out over time; possibly one, three, even seven years. Portfolio managers employed on short-term discrete contracts may be subject to exacting standards of performance and the threat of termination at-will. If insulated from short-term changes in the market pricing of talent, they may be quite strategic when playing-off internal rewards as against market opportunities.

Outsourcing: notwithstanding the benefits of in-sourcing, managers face Coase's tripartite governance problem: the difficulties of balancing the long-term benefits of in-sourcing as opposed to short-term benefits of outsourcing, systematically under- or over-investing in the infrastructure needed to oversee the internal provision of services, and the possibility that the complex nature and scope of in-sourced services will result in bureaucratic inertia and/or confusion. Here, there are a number of options, including (1) the use of a 'shadow' market for pricing the production and exchange of services internal to the institution. Leadership could also (2) establish units dedicated to facilitating the efficient coordination of complementary activities, located at the 'centre' of the institution (as represented in Figure 3 by instance E). In a related manner, (3) coordination could be facilitated by instituting a compensation regime that promotes cooperation and the sharing of responsibility for realising the objectives of the institution.

Outsourcing can be seen as yet another solution to these problems. Notice, Coase and those following in his footsteps argued that the scope of outsourcing is determined by the availability of information as to the cost and relative performance of market providers. By their account, sorting through competing service providers to find the most efficient providers incurs transaction costs repeated time and again as new market opportunities arise. In the financial services industry, this type of information is readily available. Furthermore, this information is often provided directly by service providers touting for business. Whereas the costs of service provision are readily at hand, for some types of services (notably those involving portfolio investment management) performance is only known on an ex post basis. Our institution's managers face the possibility that, however, effective they are in selecting the most cost-efficient service providers, shortfalls in performance may prompt unplanned searches for providers that promise better relative performance.

Here, there are two possible management strategies. In the first instance, rather than switching between market providers on short-term variations in costs and performance, the preferred option may be long-term contracts on the basis of absolute cost and performance contracts. In the second instance, managers may choose to hold more than two or three market providers for the same tasks and functions so as to impose discipline on each provider, while using information about market suppliers to inform any future search for related service providers.

Missing from Coase's account of the costs and benefits of outsourcing is an important issue: the rationale for choosing which tasks and functions to outsource and which tasks and functions to keep in-house. Here, again, there are two possible options. Given the cost of complexity for managing the institution, managers may choose to outsource those tasks and functions that add to the complexity of governing the institution. In this respect, governance may be aided by the retention of tasks and functions that are highly complementary and which share existing human capital and information infrastructure systems. In the same way, governance may be aided by outsourcing those tasks and functions that require more specialised or different human resources and oversight systems. By this logic, complementarity simplifies governance. External providers also require 
management and oversight. Notwithstanding transaction costs, discrete contracts can be a way of imposing discipline on these providers in ways not possible within the institution.

Tasks and functions may be outsourced on the basis of their lack of centrality to the objectives of the institution. Here, however, is a paradox. At one level, it could be argued that those tasks and functions most important to the institution ought to remain in-house and subject to the institution's governance procedures. However, at another level, recognising the risks associated with bureaucratic inertia and entrenchment, the most important tasks and functions might be outsourced so as to provide managers with the option to radically restructure and redesign their execution in the future. Whereas Coase argued that in-sourcing provides firms greater flexibility by virtue of the nature of incomplete contracts, it is entirely possible that ongoing commitment to internal teams becomes escalation in commitment such that in-sourcing becomes self-defeating (Leven 2002, p.1088). This may account for the fact that some of the largest financial institutions tend to hold routine tasks and functions, leaving innovative and difficult-to-manage tasks and functions in the marketplace subject to discrete contracts.

\section{Geographical Reach - Offshoring}

Coase's (1937) theory of the firm assumes a market, differentiated by distance from a centre-point in the landscape. In effect, the spatial reach of the firm is dictated by the costs of market information, assuming some positive relationship between distance and the costs of searching for relevant information. Likewise, in recent treatments of offshoring, the firm is assumed to be located at the heart of western consumer markets with the option of sourcing inputs to the production process from the margins of the global economy (Grossman and Rossi-Hansberg 2008). By contrast, the global financial services industry can be seen to be quite hierarchical, pivoting on just a handful of global financial centres linked through national and regional financial centres to the notional consumers of financial products (Wójcik 2011). In the global financial services industry, 'consumers' are decentralised whereas 'producers' are highly centralised.

It was noted above that in-sourcing and outsourcing are management options, mediated by the institution's rate of return target, strategic assets, and assets-under-management. It was also noted that in-sourcing and outsourcing may have distinctive geographical footprints, just as offshoring may be within and without the institution. In this section, we look more closely at the imperatives behind offshoring, treating in-sourcing and outsourcing as expressions of this phenomenon. As before, we assume there are two types of financial institutions: small and large wherein the former do not have sufficient assets-under-management to do much more than govern a network of external suppliers in accordance with their rate of return targets. By contrast, large institutions are assumed to have the option to in-source and outsource. For the sake of exposition, we also assume that our institution occupies either a core market location (being at or adjacent to a global financial centre) or a peripheral market location (closer to beneficiaries than financial markets).

\section{[Insert Figure 4 about Here]}

In Figure 4, we provide a $2 \times 2$ box summarising the options facing institutions, given their size (assets-under-management) and location. Size represents the governance capacity or potential of the institution - in effect, the bottom left-hand corner of Figure 3 joins together the coordination and authority functions of our institution's managers. With a core location, a small financial institution at the centre of the global financial services industry is likely able to reap the benefits of relatively low search and transaction costs. Being at the centre of the global financial services industry, even a small institution is able to access relatively sophisticated financial products which have 'global' reach. Even so, access to these types of products may be limited by the minimum size of investment required by major investment houses. Access may also be limited by the institution's 
capacity to hire and retain specialised portfolio managers and executives with well developed industry networks. Relational contracts may be essential for maintaining their human capital.

By contrast, small institutions located in peripheral market locations face relatively high search and transaction costs. These types of institutions must rely upon third-party information providers whether through the electronic medium or through consulting and advisory companies that specialise in industry-wide information. While the electronic medium is often highly efficient, distributing information across the landscape to provincial centres without any apparent loss of immediacy, it is widely recognised that this type of information provides little in the way of market advantage. Furthermore, having a peripheral location in relation to a major financial centre is likely to incur a discount on returns (Wójcik 2011). Consulting and advisory companies are particularly effective in packaging information. Nonetheless, the effective use of this information depends a great deal on the skills and expertise of managers; otherwise, they may come to rely upon consulting companies for strategic investment policy as well as the choice of portfolio managers. By default, the preferred management strategy may be to outsource, even offshore, crucial functions related to fund governance (coordination and authority).

Large institutions located in core financial markets may benefit from low search and transaction costs. Furthermore, being of sufficient size to choose whether to in-source and outsource, managers may be able to design and configure the institution in accordance with the relative benefits of insourcing versus outsourcing by specific tasks and functions. If this is one of their roles and responsibilities, to give effect to these types of strategies may require executives to have long-term relational contracts that lock-in their career and compensation prospects to the performance of the institution. At the other end of the spectrum, however, a large and vibrant market for financial services may make it very difficult for executives to retain talented staff on anything other than short-term, discrete contracts. In this environment, tournaments for staff may dominate the market for financial services, forcing managers to choose which tasks and functions they can hold internally and which tasks and functions can only be obtained externally. Exercising this choice is likely to involve consideration of the costs of coordination, as well as task and function complementarities.

By this logic, large institutions located in core financial markets have permeable boundaries and contingent relationships internal and external to the institution. By contrast, large institutions located in peripheral sites relative to core financial markets face considerable challenges. Unlike small institutions, they have the governance capacity to be an effective presence, even at a distance, in global financial centres. Furthermore, they may benefit from a steady stream of product providers willing to incur the transaction costs involved in providing market insights and information at the institution's headquarters. Just as importantly, a peripheral location may enable the institution to hold its skilled portfolio managers without incurring the same level of compensation costs characteristic of similar institutions located in core financial markets. However, there is a significant trade-off between in-sourcing and outsourcing: it may be very difficult indeed to hold the most skilled and talented employees responsible for executing specialised tasks and functions that carry a market premium. Managers may be forced to outsource and even offshore these functions.

Large institutions in peripheral locations may, in fact, be tempted to establish branch offices or wholly-owned subsidiaries in core markets. This is an offshoring strategy internal to the institution; it is a means of economising on search and transaction costs, channelling market information and insights through the existing information infrastructure systems owned and operated by the institution. Here, there is a premium on 'governance at a distance' - the internal coordination and management of separate entities in a manner consistent with the overarching goals and objectives of the institution. At one level, this type of strategy in-sources but offshores tasks and functions so as to overcome the costs of a peripheral location. At another level, however, this strategy has its 
own tensions and dilemmas. For example, whether to carry-over to separate entities the same governance systems and employment contracts characteristic of the home location. Equally problematic, the privileged location of these separate entities may provide them the informal 'authority' to circumvent the institution's strategic investment policies. ${ }^{5}$ Ultimately, the scope of this type of offshore strategy may be circumscribed by 'home' managers concerned to maintain a coherent and integrated governance regime (and culture) across the institution.

\section{Conclusions}

In this paper, we have sketched the principles or building blocks for understanding the functional and geographical scope of investment institutions. Our analysis eschews the details of specific institutions and their particular jurisdictions, suggesting that our conceptual building blocks are important in their own right and join together the experience of similar institutions around the world. Of course, there is a trade-off between conceptual abstraction and the nitty-gritty of time and place - here we have chosen the former over the latter in the interests of clarity. Elsewhere we have provided detailed case studies of the structure and management of sovereign wealth funds (one particular kind of investment institution) (see Clark and Monk 2012). As noted in the introduction to this paper, understanding the functional and geographical scope of investment institutions is an important project, although largely ignored across the social sciences (see, as an exception, Dixon and Monk 2012).

Inspiration for the paper has come from a close reading of Coase's (1937) seminal paper on the nature of the firm, its organising principles, and its significance relative to market transactions. We draw also upon more recent research that emphasises the nature and structure of service contracts within and without firms. Furthermore, we exploit Coase's interest in the geographical reach of the modern firm and how his entrepreneur-coordinators deal with the transaction costs of space as well as time. It is noted that his interest in this topic has been developed by Grossman and RossiHansberg (2008). Their model of offshoring depends upon communication technologies in mediating the transaction costs involved with contracting at a distance. While significant for our analytical framework, it is also apparent that the focus of scholars of the theory of the firm is on institutions that literally make things, exchange commodities, and sell commodities in the global marketplace.

A crucial point of departure for the paper is the objective function of our idealised financial institution: the maximisation of the risk-adjusted rate of return. We explain how this is operationalised and how its various elements drive the 'production' of the financial 'product'. Importantly, we distinguish our idealised financial institution from conventional firms on the basis of the nature and scope of its strategic assets. Unlike conventional industrial firms, financial institutions have little in the way of tangible or fixed assets: they rely upon human capital, governance procedures and policies, and systems of information infrastructure that allow for oversight of its operations and access to the global financial system. It is debatable whether these strategic assets are actually assets in the sense that, like plant and equipment, they could be sold to the highest bidder. In many respects, these assets are sunk costs (Clark and Wrigley 1997): representing significant investments which, to competitors, may be seen as comparative advantages in realising investment goals.

\footnotetext{
$5 /$. In these ways, offshore offices that carry with them a team-based ethic or sensibility may see themselves as rather separate from the sponsoring institution's goals and objectives. As is the case with many portfolio investment teams, the premium on internal coherence and common commitment may reinforce a sense of separate-and-different amplified by differences between jurisdictions in compensation practices, reward systems, and career prospects.
} 
Based upon these distinctions, we explain the nature of the governance problem in large and small financial institutions. Likewise, we explain how and why those that produce financial returns have distinctive claims for compensation and advantage in their own right. On this basis, utilising our characterisation of the strategic assets of financial institutions, we explain the logic behind insourcing and outsourcing and, ultimately, the geographical reach of financial institutions. Whereas the logic behind in-sourcing and outsourcing may be familiar, we suggest that offshoring or the geographical reach of financial institutions is intimately related to their location in the global hierarchy of financial centres. Indeed, quite unlike conventional models of the firm, which treat the market for services as ubiquitous, in our formulation it matters a great deal where financial institutions are located relative to national and global financial centres.

It was noted that Coase believed there are decreasing returns to scale in the sense that the increasing complexity of a firm's tasks and functions may become costly relative to the market for services and thereby prompt managers to switch to outsourcing. We also emphasise the coordination problems associated with large financial institutions, suggesting that managers may seek to mediate these costs by introducing internal or shadow markets for services produced by the institution. As well, managers may establish coordination platforms and virtual sites of functional integration designed to rationalise service provision and use. These types of management strategies focus upon the complementarities between tasks and functions, whereas outsourcing, even offshoring, should be understood as driven by the lack of complementarity of certain tasks and functions. This argument reflects a related point made by Clark (2002) about why certain financial tasks and functions are concentrated in single sites of 'production' characteristic of bulge-bracket global investment houses.

Finally, it should be acknowledged that our models of management assume that managers are wellintentioned and have, as their overriding interest, the welfare of beneficiaries and customers. While useful for the purposes of conceptual clarity and analysis, this assumption may not withstand empirical scrutiny in certain cases. Indeed, industry commentators acknowledge that there are many instances of executive entrenchment based upon in-sourcing which drives the scope of the institution and ultimately the compensation of managers. This would seem to be an ever-present threat to the effective governance of these institutions. Not surprisingly, one way of mediating this possibility is to link the objective function of the institution (maximising returns) explicitly to the welfare of its ultimate beneficiaries and customers. Whether this is a successful strategy would seem to depend upon the degree to which internal cultures of value can be distinguished from the interests of talented individuals in reaping a premium in the global market for financial services. This issue is significant for financial regulators around the world.

\section{Bibliography}

Allen, F., and Gale, D. (1994), Financial innovation and Risk Sharing. Cambridge, Mass.: MIT Press.

Baker, G., Gibbons, R. and Murphy, K. J. (2002), 'Relational contracts and the theory of the firm', Quarterly Journal of Economics 117: 39-84.

Bathelt, H. and Glückler, J. (2011), The Relational Economy: Geographies of Knowing and Learning. Oxford: Oxford University Press.

Che, Y-K and Woo, S-W. (2001), 'Optimal incentives for teams', American Economic Review 91: 52541. 
Clark, G. L. (1981), 'The employment relation and spatial division of labor: a hypothesis', Annals, Association of American Geographers 71: 412-24.

Clark, G. L. (1994), 'Strategy and structure: corporate restructuring and the scope and characteristics of sunk costs', Environment and Planning A 26: 9-32.

Clark, G.L. (2000), Pension Fund Capitalism. Oxford: Oxford University Press.

Clark, G. L. (2002), 'London in the European financial services industry: locational advantage and product complementarities', Journal of Economic Geography 2: 433-53.

Clark, G.L. (2008), 'Governing finance: global imperatives and the challenge of reconciling community representation with expertise', Economic Geography 84: 281-302.

Clark, G. L. and Monk, A. H. B. (2012), Sovereign Wealth Funds. Princeton: Princeton University Press (forthcoming).

Clark, G.L. and Wrigley, N. (1997), 'Exit, the firm and sunk costs: re-conceptualising the corporate geography of disinvestment and plant closure', Progress in Human Geography 21: 338-58.

Coase, R. H. (1937), 'The nature of the firm', Economica 4: 386-405.

Currah, A. and Wrigley, N. (2004), 'Networks of organisational learning and adaptation in retail TNCs', Global Networks 4:1-23.

Dicken, P. (2000), 'Places and flows: situating international investment', in The Oxford Handbook of Economic Geography edited by G.L. Clark, M.P. Feldman, and M.S. Gertler. Oxford: Oxford University Press, pp. 275-291.

Dicken, P. and Malmberg, A. (2001), 'Firms in territories: relational perspective', Economic Geography 77: 345-63.

Dixon, A. D. (2011), 'Variegated capitalism and the geography of finance: towards a common agenda', Progress in Human Geography 35: 193-210.

Dixon, A. D. (2012), 'Function before form: macro-institutional comparison and the geography of finance', Journal of Economic Geography doi:10.1093/jeg/lbr043

Dixon, A.D. and Monk, A.H.B. (2012), 'Rethinking the sovereign in sovereign wealth funds', Transactions of the Institute of British Geographers 1: 104-117.

Dore, R. (2000), Stock Market Capitalism: Welfare Capitalism. Japan and Germany versus the AngloSaxons. Oxford: Oxford University Press.

Easterbrook, G. and Fischel, D. (1991), Economic Structure of Company Law. Cambridge MA: Harvard University Press.

Gertler, M. S. (2003), 'Tacit knowledge and the economic geography of context, or the undefinable tacitness of being (there)', Journal of Economic Geography 3: 75-99. 
Grossman, G. M. and Helpman, E. (2005), 'Outsourcing in a global economy', Review of Economic Studies 72: 135-59.

Grossman, G. M., and Rossi-Hansberg, E. (2008), 'Trading tasks: a simple theory of offshoring, American Economic Review 98: 1978-97.

Grossman, S.J. and Stiglitz, J. (1980), 'On the impossibility of informationally efficient markets', American Economic Review. 70: 393-408.

Grossman, S.J., Kihlstrom, R.E., and Mirman, L.J. (1977), A Bayesian approach to the production of information and learning by doing. Review of Economic Studies 44: 533-47.

Hall, P. and Soskice, D. (2001), Varieties of Capitalism: The Institutional Foundations of Comparative Advantage. Oxford: Oxford University Press.

Hart, O. (1995), Firms, Contracts, and Financial Structure. Oxford: Oxford University Press.

Hart, O. and Holmstrom, B. (2010), 'A theory firm scope', Quarterly Journal of Economics 125: 483513.

Hart, O. and Moore, J. (1999), 'Foundations of incomplete contracts', Review of Economic Studies 66:115-38.

Hilton, D. (2003), 'Psychology and the financial markets: applications to understanding and remedying irrational decision-making', in Brocas, I. and Cartillo, J.D. (eds): The Psychology of Economic Decisions. Volume 1: Rationality and Well-Being. Cambridge: Cambridge University Press, pp. 273-97.

Holmstrom, B. and Milgrom, P. (1994), 'The firm as an incentive system', American Economic Review 84: 972-91.

Jensen, M. J. (1993), 'The modern industrial revolution, exit, and the failure of internal control systems', Journal of Finance 48: 831-80.

Jensen, M. J. (2001), A Theory of the Firm. Cambridge MA: Harvard University Press.

Kahneman, D. and Tversky, A. (1979), 'Prospect theory: an analysis of decision under risk', Econometrica, 47: 263-91.

Knight, F. (1921), Risk, Uncertainty, and Profit. Boston: Houghton Mifflin Company.

Leven, J. (2002), 'Multilateral contracting and the employment relationship', Quarterly Journal of Economics 117: 1075-103.

Lowe, M. and Wrigley, N. (2010), 'The "continuously morphing" retail TNC during market entry: Interpreting TESCOs expansion in to the USA', Economic Geography 86: 381-408.

Macneil, I. R. (1980), The New Social Contract: An Enquiry into Modern Contractual Relations. New Haven: Yale University Press.

Maskell, P. (2001), 'The firm in economic geography', Economic Geography 77:329-44. 
Monk, A. H. B. (2008), 'The knot of contracts: the corporate geography of legacy costs', Economic Geography 84: 211-35.

Morrison, A. D. and Wilhelm, W. J. (2007), Investment Banking: Institutions, Politics, and Law, Oxford: Oxford University Press.

Pratt, J. and Zeckhauser, R. (Eds) (1985), Principals and Agents: The Structure of Business, Boston: Harvard Business School Press.

Roberts, J. (2004), The Modern Firm: Organisational Design for Performance and Growth, Oxford: Oxford University Press.

Schoenberger, E. (1997), The Cultural Crisis of the Firm, Oxford: Blackwell.

Spence, M. J. (1977). Consumer misperceptions, product failure and producer liability. Review of Economic Studies 44: 561-72.

Taylor, M. J. and Asheim, B. (2001), 'The concept of the firm in economic geography', Economic Geography 77: 315-28.

Thakor, A. V. (1996), 'The design of financial systems: an overview', Journal of Banking and Finance 20: 917-48.

Teece, D. (2000), Managing Intellectual Capital. Oxford: Oxford University Press.

Wagner, R. K. (2002), 'Smart people doing dumb things: the case of managerial incompetence', in Sternberg, R.J. (ed.): Why Smart People Can be so Stupid. New Haven: Yale University Press, pp. 4263.

Williamson, O. (1975), Markets and Hierarchies, New York: Free Press.

Wójcik, D. (2011), The Global Stock Market, Oxford: Oxford University Press.

Woods, C. (2011), The environment, intergenerational equity and long-term investment, DPhil Thesis: Oxford: University of Oxford.

Wrigley, N., Coe, N. M., and Currah, A. (2005), 'Globalizing retail: conceptualising the distributionbased transnational corporations (TNCs)', Progress in Human Geography 29: 437-57. 
Figure 1. Contractual regimes

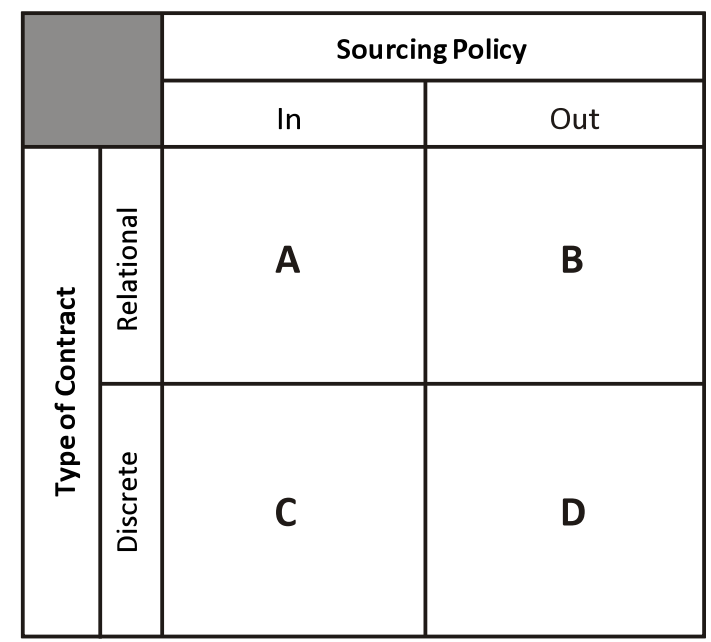

Figure 2. Sourcing options

\begin{tabular}{|c|c|c|c|}
\hline & \multicolumn{2}{|c|}{ Sourcing Policy } \\
\hline & & In & Out \\
\hline \multirow{2}{*}{ 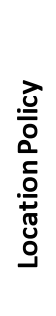 } & $\stackrel{\check{g}}{\tilde{c}}$ & A & B \\
\hline & 产 & C & D \\
\hline & & & \\
\hline
\end{tabular}

Figure 4. Strategic scope

\begin{tabular}{|c|c|c|c|}
\hline & \multicolumn{2}{|c|}{ Assets-under-Management } \\
\hline & & Small & Large \\
\hline \multirow{2}{*}{ 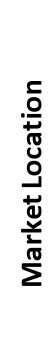 } & $\stackrel{0}{\circ}$ & A & B \\
\hline & 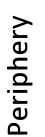 & C & D \\
\hline & & & \\
\hline
\end{tabular}


Figure 3. Intangible assets

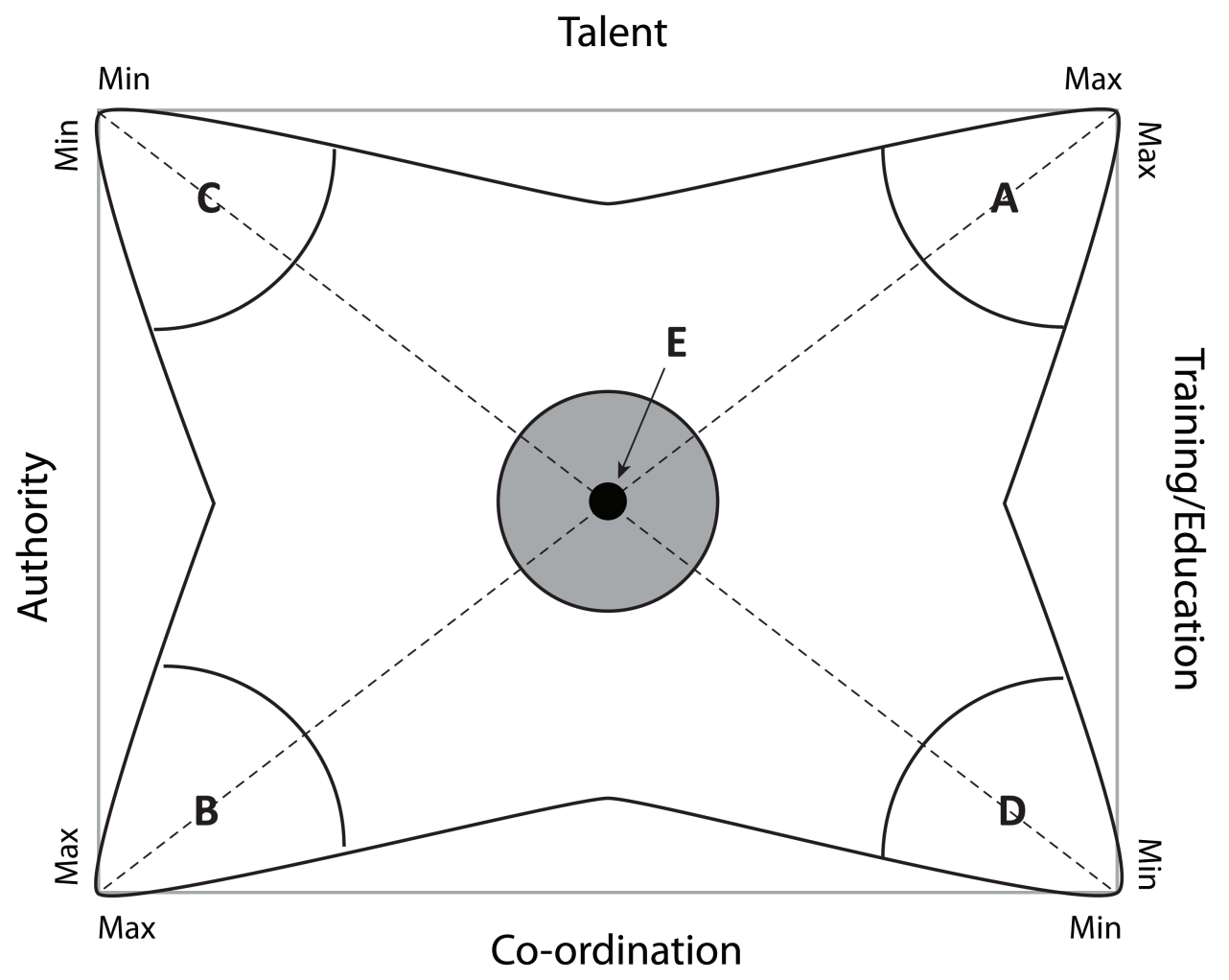

